at Cambridge, Massachusetts, was celebrated as an outstanding event in the history of knowledge by a great gathering representative of all branches of learning and drawn from all parts of the world. A tribute of a different character came from six of the industrial leaders of the United States, in the form of a letter to President Conant directing attention to the indebtedness of American industry to the universities. They pointed to the large and increas. ing number of university trained men in industry and business as evidence of the influence of university education on industrial progress, and stated that, having caught the spirit of research from the universities, industry has applied its methods successfully and with noteworthy results. During the past twenty-five years, the number of industrial research laboratories in the United States has grown from a handful to more than 1500 , and is rapidly increasing. "From the universities also flows much of the basic knowledge of science on which modern technical industry has built and will build in the future." The letter is signed by Walter S. Gifford, president of the American Telephone and Telegraph Company ; Alfred P. Sloan, jun., president of the General Motors Corporation; Thomas G. Watson, president of the International Business Machines Corporation; Pierre S. du Pont, chairman of the board of E. I. du Pont de Nemours and Company ; Owen D. Young, chairman of the board of the General Electric Company; and Walter C. Teagle, president of the Standard Oil Company of New Jersey. It is a striking tribute to the significance of university institutions in industrial progress.

\section{African Problems}

A WIDE and varied field was covered in the discussions which engaged the attention of the twenty. third biennial session of the International Colonial Institute held in London on October 6-8. As Mr. Ormsby-Gore pointed out in a speech at the banquet at which the delegates were entertained by the British Government, the Colonial Powers are all confronted with a number of problems, human, political and social, which have to be studied objectively in common. To this end the mere interchange of views and experience is useful, even though no very decisive conclusion may appear to emerge. In this respect, the pooling of experience and discussion of methods of meeting the new problems raised by the introduction of newspapers, broadcasting and the cinema are highly instructive. This, too, is perhaps the most beneficial outcome it is legitimate to expect from the discussion of the detribalized native, which was opened by Lord Lugard and occupied a considerable part of the session. It was evident, as might have been anticipated, that measures applicable to one area may not be possible in another. Thus the conclusion put forward by Father Charles, that tribalism can be revived successfully only under rule on tribal lines and by the use of native courts, may be accepted as a general proposition. Clearly, however, it cannot meet transitional cases, such as those to which $\mathrm{Mr}$. Ormsby-Gore referred, when he spoke of the product emerging under missionary influence, for example, in the towns of the west coast, which it is difficult to fit into the evolution and progress of tribal life and the social organism. On the other hand, Prof. Basil Williams, while expressing approval of the system in the Belgian Congo, under which the mine-workers are encouraged to bring their wives, admitted that it has been impressed upon him that such a system would not be practical on the Rand, where mineworkers number a quarter of a million.

\section{Natural Resources Conservation}

ONE of the important questions discussed at the recent World Power Conference was the conservation of natural resources. Science Service, of Washington, D.C., has issued reports of papers, dealing with this subject, which formed the basis of a discussion at the Conference. It is stated that whether the business systems are capitalist or socialist or a combination of the two, we must organize our activities to meet the demands of natural law, and all civilized nations are struggling towards this end each in its own way. The principles laid down for 'resource planning' by the writer of the reports are to keep soil, water, forest and grass as at present, but to economize by every possible means in the use of irreplaceable minerals. Nature lays down the terms, and we must either obey or suffer. We can come to terms with Nature in regard to the self-renewing resources by using them only as fast as they are replaced. With regard to the non-replaceable minerals, we can come to terms only by finding new and abundant substitutes faster than we use up the older materials. It is a race between technology and waste. Face to face with the inexorable demands of Nature, we suffer from human weakness. The consent of the people has to be obtained in spite of the propaganda issued by those whose interests are opposed to the public welfare. The laws of a federal union of sovereign States are a tangle of inconsistent rights and powers that hampers the action of the nation. The United States are now struggling to acquire legal and political powers commensurate with their necessities. If it fails, we are thruatened by a crisis when essential materials are exhausted and it becomes necessary to reduce the population.

\section{British Chemical Manufacturers}

REPoRtING on its activities during the year ended May 31, 1936, the Association of British Chemical Manufacturers justly claims to have rendered substantial assistance to an industry which is one of our most important national assets. It is concerned with the organization of displays of British goods, such as that provided by the British Industries Fair, with legislation and the incidence of taxation, with commercial treaties with foreign countries, with the Ottawa agreements and means for stimulating trade within the Empire, with transport, safety precautions, and in fact with any problem relating to the industry other than questions involving wages, hours and conditions of work. There is, however, much still to be done, and the Association is anxious to realize 